\title{
Occurrence of Selenisa sueroides (Guenée, 1852) (Lepidoptera: Noctuidae) in soybeans in Brazil
}

\author{
Ocorrência de Selenisa sueroides (Guenée, 1852) \\ (Lepidoptera: Noctuidae) em soja no Brasil

\section{Ricardo Oliveira dos Santos ${ }^{1 *}$, Paulo Eduardo Degrande ${ }^{1}$, Rosalia Azambuja ${ }^{2}$, Ellen Patrícia de Souza²}

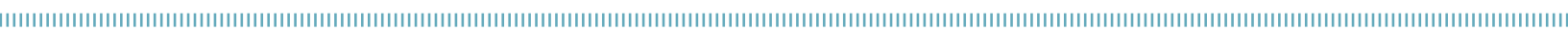

\begin{abstract}
In this study, we report the occurrence of Selenisa sueroides (Guenée, 1852) in soybean crops in Brazil. S. sueroides worms were observed defoliating soybean crops in the municipality of Itaporá, state of Mato Grosso do Sul. The occurrence of this species has also been reported in the cities of Laguna Carapá, Itaquiraí, Dourados, Aral Moreira, and Chapadáo do Sul, all in the same state, and the municipality of Campo Novo do Parecis, in Mato Grosso state.
\end{abstract}

KEYWORDS: defoliation; first report; soybean looper; Glycine $\max \mathrm{L}$.
RESUMO: Neste trabalho é relatada a ocorrência de Selenisa sueroides (Guenée, 1852) na cultura da soja no Brasil. S. sueroides foi observada desfolhando a cultura da soja no município de Itaporã, Mato Grosso do Sul. A ocorrência da espécie vem sendo notada também nas cidades de Laguna Carapá, Itaquiraí, Dourados, Aral Moreira e Chapadão do Sul, no mesmo estado, além do município de Campo Novo do Parecis, no Mato Grosso.

PALAVRAS-CHAVE: desfolha; primeiro registro; lagartapinça; Glycine max L. 
Selenisa sueroides (Guenée, 1852) (Lepidoptera: Noctuidae) is a polyphagous species that has been reported in legumes (Fabaceae, Mimosaceae, Caesalpiniaceae), Poaceae, and Euphorbiaceae (ZAGATTI et al., 1995), and it is well known feeding others plants. This study reports the occurrence of S. sueroides in soybean crops in the state of Mato Grosso do Sul, besides other occurrences of this species in this crop in Brazil.

Brushwein et al. (1989) and Brushwein; ChILders (1990) reported the appearance of $S$. sueroides in irrigated citrus groves in southwest Florida in 1987. In addition to citrus, this species has been observed in Fabaceae (BRUshweIN et al., 1989). Formentini et al. (2009) cite the occurrence of this species associated with soybean crops in Honduras and Nicaragua. According to WAGNER et al. (2011), S. sueroides has been found in Acacia, Pithecellobium, senna, and other legumes in Florida and Texas, and it is becoming common in subtropical areas, where it is active year-round.

In Brazil, there have been reports of $S$. sueroides moths being collected in light traps in areas of crops and cerrado in Balsas, Maranháo (CAmargo, 2001). More recently, in Vale dos Vinhedos, in serra gaúcha, a $S$. sueroides moth was collected in grape vines (ZENKER et al., 2010).

Specimens of $S$. sueroides were collected in December 2014 , in the municipality of Itaporã (2204'56"S, 54\%47'20"W; $351 \mathrm{~m}$ altitude), Mato Grosso do Sul, Brazil. The caterpillar (Fig. 1), initially named "lagarta-pinça", was found in soybean plants, variety NA 5909 RR, vegetative stage V4, in a wet lowland of the Água Boa Farm, property of George Louveira Matoso. Damage was more severe at the field edges, which also was observed visually. All specimens exhibited the habit of defoliating plants.

The caterpillars were sent to the Laboratory of Applied Entomology of Universidade Federal da Grande Dourados (UFGD), maintained in rearing facilities at $25 \pm 2{ }^{\circ} \mathrm{C}$, $70 \pm 10 \%$ relative humidity, and photoperiod of 12 hours in order to obtain adults. They were kept in plastic containers $(100 \mathrm{~mL})$ and fed soybean leaves variety BMX Potência until reaching the pupal phase (Fig. 2).The adults (Fig. 3) obtained were maintained in cylindrical polyvinyl chloride (PVC) cages $(15 \times 22 \mathrm{~cm})$ and fed a $10 \%$ honey solution in an attempt to rear the species under laboratory conditions, which was unsuccessful. The duration of the pupal phase was 15 days ( $\mathrm{n}=7$ pupae), and adult life span, 16 to 18 days ( $\mathrm{n}=5$ individuals).

The specimens were identified in the Laboratory of Applied Entomology of UFGD as S. sueroides by Biol. MSc. Ellen P. de Souza, and this is the first report of this species in soybean crops in Brazil.

Due to its remarkable morphological difference in the larval stage of other species of defoliating caterpillars commonly found in the region, supposed the visit reports of the field it the same species, which between 2006 and 2007 in the city of Chapadáo do Sul, Mato Grosso do Sul, in the forage legume Stylosanthes. However, the populations were small, without economic importance. In 2013 in a property located in the municipality of Itaquiraí, also in Mato Grosso do Sul, a small population of this species was reported in the soybean variety BMX Potência, reproductive stage R5.2, causing damage due to defoliation.

More recently, in the city of Itaporá species supposedly has also been observed in the cities of Laguna Carapã, Aral Moreira, Itaquiraí and Dourados. Later, adult specimens were captured in a light trap at the UFGD. Caterpillars of $S$. sueroides have also been noticed in soybean crops in the state of Mato

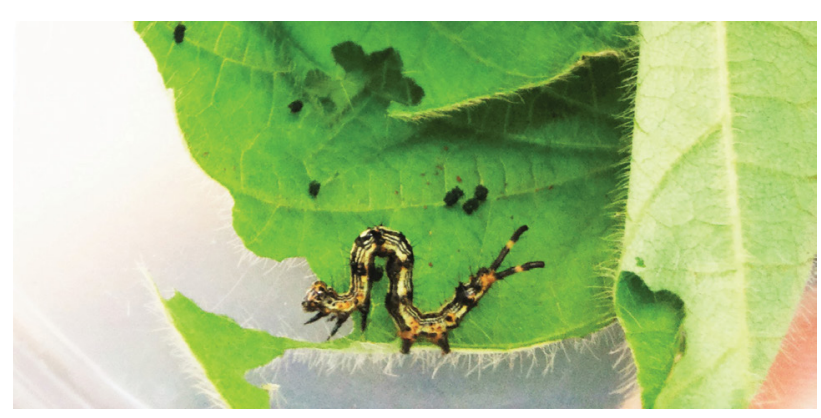

Figure 1. Caterpillar Selenisa sueroides (Guenée, 1852) (Lepidoptera: Noctuidae).

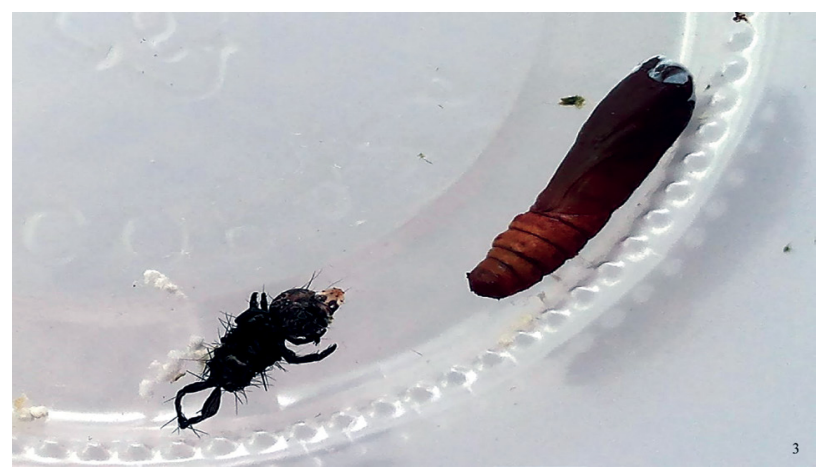

Figure 2. Pupae and exuvia of Selenisa sueroides (Guenée, 1852) (Lepidoptera: Noctuidae).

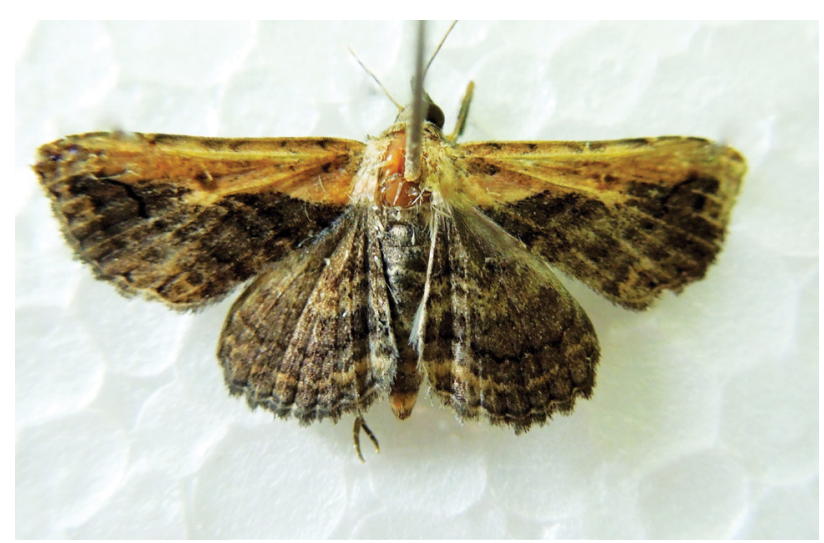

Figure 3. Adult of Selenisa sueroides (Guenée, 1852) (Lepidoptera: Noctuidae). 
Grosso. In the municipality of Campo Novo do Parecis, Mato Grosso, this species was more commonly found at the edge of stands, showing the beginning of the installation on the farm. In this case, no damage was verified or did not require control measures.

It is assumed that $S$. sueroides populations are reduced with the simultaneous control of other caterpillars, where most of the pesticides used is effective to control it.

The recent reports of occurrence of $S$. sueroides in soybean crops of 2014/2015 indicate that studies on this species are needed, as its defoliating habit might become a problem to soybean crops in Brazil.

\section{ACKNOWLEDGMENTS}

The authors thank George Louveira Matoso and Daniel Cesar Nepomuceno for samples, and Thiago Ferreira Bertoncello for additional reports in the field.

\section{REFERENCES}

BRUSHWEIN, J.R.; CHILDERS, C.C. Parasitoids associated with the immature stages of Selenisa sueroides (Lepidoptera: Noctuidae). The Florida Entomologist, Florida, v.73, n.2, p.337-339, 1990. Available from: <http://www.jstor.org/stable/3494821>. Accessed on: 28 jan. 2015.

BRUSHWEIN, J.R.; MATTHEWS, C.H.; CHILDERS, C.C. Selenisa sueroides (Lepidoptera: Noctuidae): a pest of subcanopy irrigation systems in citrus in southwest Florida. The Florida Entomologist, Florida, v.72, n.3, p.511-518, 1989. Available from: <http:// www.jstor.org/stable/3495191 >. Accessed on: 27 jan. 2015.

CAMARGO, A.J.A. Diversidade de insetos em áreas cultivadas e reserva legal: considerações e recomendações. Planaltina: Embrapa Cerrados, 2001.27p. (Boletim de Pesquisa e Desenvolvimento, n. ${ }^{0} 1$ ). Available from: <https://www.agencia.cnptia.embrapa.br/recursos/Diversidade_ InsetosID-loDNxD5fx6.pdf>. Accessed on: 29 jan. 2015.

FORMENTINI, A.C. Lepidópteros associados à cultura da soja: diversidade e parasitismo natural por insetos e fungos entomopatogênicos. 2009. 69p. Dissertação (Mestrado em Biotecnologia) - Instituto de Biotecnologia Universidade de Caxias do Sul, Universidade de Caxias do Sul, Caxias do Sul, 2009. Available from: <https://repositorio.ucs.br/jspui/ handle/1 1338/490>. Accessed on: 30 jan. 2015.

WAGNER, D.L.; SCHWEITZER, D.F.; SULLIVAN, J.B.; REARDON, R.C. Owlet caterpillars of eastern North America (Lepidoptera: Noctuidae). New Jersey: Princeton University Press, 2011.

ZAGATTI, P.; LALANNE-CASSOU, B.; D'AUBIGNY, J.LeD. Catalogue des lépidoptères des Antilles françaises. Institut National de la Recherche Agronomique, 1995. Available from: <http://www7.inra. $\mathrm{fr} /$ papillon/noctuid/ophideri/texteng/s_sueroi.htm>. Accessed on: 28 jan. 2015

ZENKER, M.M.; BOTTON, M.; TESTON, J.A.; SPECHT, A. Noctuidae moths occurring in grape orchards in serra gaúcha, Brazil and their relation to fruit-piercing. Revista Brasileira de Entomologia, São Paulo, v.54, n.2, p.293, 2010. 